\title{
Estimating Mangrove Forest Volume Using Terrestrial Laser Scanning and UAV-Derived Structure-from-Motion
}

\author{
Angus D. Warfield * and Javier X. Leon (1) \\ School of Science and Engineering, University of the Sunshine Coast, 90 Sippy Downs Dr, \\ Sippy Downs, QLD 4556, Australia; jleon@usc.edu.au \\ * Correspondence: awarfiel@usc.edu.au
}

Received: 6 March 2019; Accepted: 28 March 2019; Published: 1 April 2019

check for updates

\begin{abstract}
Mangroves provide a variety of ecosystem services, which can be related to their structural complexity and ability to store carbon in the above ground biomass (AGB). Quantifying AGB in mangroves has traditionally been conducted using destructive, time-consuming, and costly methods, however, Structure-from-Motion Multi-View Stereo (SfM-MVS) combined with unmanned aerial vehicle (UAV) imagery may provide an alternative. Here, we compared the ability of SfM-MVS with terrestrial laser scanning (TLS) to capture forest structure and volume in three mangrove sites of differing stand age and species composition. We describe forest structure in terms of point density, while forest volume is estimated as a proxy for AGB using the surface differencing method. In general, SfM-MVS poorly captured mangrove forest structure, but was efficient in capturing the canopy height for volume estimations. The differences in volume estimations between TLS and SfM-MVS were higher in the juvenile age site $(42.95 \%)$ than the mixed $(28.23 \%)$ or mature $(12.72 \%)$ age sites, with a higher stem density affecting point capture in both methods. These results can be used to inform non-destructive, cost-effective, and timely assessments of forest structure or AGB in mangroves in the future.
\end{abstract}

Keywords: mangroves; forest structure; terrestrial laser scanning; structure-from-motion

\section{Introduction}

Mangrove forests are a woody vegetation that grow predominantly in tropical regions in more than 100 countries and territories worldwide [1]. Located at the interface between land and sea, mangroves provide dozens of ecosystem services ranging from local to global scales, including shoreline stabilization [2], storm protection [3], and habitat [4]. The ability of mangroves to sequester carbon is impressive, with estimates of $1023 \mathrm{Mg}$ carbon stored per hectare [5], which is more efficient per unit area than any other tropical forest type [6]. However, mangroves are being lost at an alarming rate due to land use change, deforestation, and the impacts of climate change [7-9], thereby converting potential carbon sinks into sources [10]. Quantifying carbon storage is essential to retain the ecological and economical integrity of these ecosystems [8,11,12], by highlighting their potential to mitigate climate change and ensuring their future conservation [13].

The estimation of above-ground biomass (AGB) is an important indicator for carbon storage, as it represents a lower bound for the total biomass within an ecosystem [14]. Mangroves can vary considerably in $\mathrm{AGB}$, from $500 \mathrm{Mg} / \mathrm{ha}$ in riverine areas to $<8 \mathrm{Mg} /$ ha for dwarf mangrove stands [15]. Traditional AGB assessments utilise direct harvesting methods, which are accurate, but time-consuming, costly, and destructive [16,17], and prone to subjective errors [18]. The measurement of forest structure, which refers to the horizontal and vertical arrangement of physical attributes, such as trunks and branches [19], has been used to develop less-destructive estimates of AGB. Structural attributes can be used to estimate carbon storage by developing species-specific allometric equations, which establish a 
relationship between easily measurable traits, such as the diameter at breast height (DBH) and specific gravity (wood density), and AGB [20]. Carbon content can be estimated relatively simply by multiplying AGB by the carbon concentration, which varies among species, but is generally between $45.9 \%$ and $47.1 \%$ in mangroves [11]. Allometric equations have produced good agreement with destructively harvested data [11], however, still require intensive field surveys and initial harvesting [20], and may not be representative of the regional species distribution [21,22]. Therefore, non-destructive estimates of AGB are being adopted using remote sensing technology that allows the rapid capture of forest structure, without substituting the level of accuracy needed to inform carbon accounts [23].

The use of light detection and ranging (LiDAR) has become common practice for capturing forest structure to estimate AGB [24]. Full-waveform LiDAR measures the shape of the pulse along its transmission path as it interacts with surrounding objects [25]. Full-waveform LiDAR sensors may be attached to aircraft, referred to as airborne laser scanning (ALS), or attached to ground-based platforms, referred to as terrestrial laser scanning (TLS) [23]. ALS is commonly adopted for large scale forest inventories, often capturing around 2 to 20 points per $\mathrm{m}^{-2}$ depending on the sensor [24], whereas TLS scanners are often utilised for plot scale assessments and can capture up to $\sim 1$ million points per second [22], providing upwards of 1000 points per $\mathrm{m}^{-2}$ [26]. TLS can also capture a wealth of structural information to estimate AGB that shows good agreement with destructively harvested biomass [27]. However, TLS scanners can cost up to $\$ 35,000$ USD [28], and surveying and processing times can be burdensome [26].

LiDAR sensors attached to unmanned aerial vehicles (UAVs) may offer a more cost-effective alternative to TLS, while also increasing the spatial and temporal resolution of traditional ALS [28]. However, suitable inertial measuring units (IMUs) and a global navigation satellite system (GNSS) are required for accurate positioning [23], making commercially available UAV systems costly [29].

An alternative to LiDAR is the use of structure-from-motion (SfM) technology [30], which has been used to estimate AGB across a variety of ecosystems [31-34]. The SfM method is a photogrammetric workflow that uses computer matching of common points in overlapping two-dimensional images to produce a three-dimensional (3D) point cloud, which is increased in magnitude using a multi-view stereo (SfM-MVS) [30]. This workflow can be utilised with photographs taken on-ground, referred to as 'terrestrial close-range photogrammetry' [35], which has been successful for estimating AGB [33] and tree volume [36,37] for forest inventories. However, given the muddy and inaccessible terrain associated with mangroves, UAVs may represent a more attractive alternative.

UAV derived imagery combined with SfM-MVS algorithms provide an inexpensive method for estimating AGB in forested environments [31,38-40]. This method can acquire accurate estimates of forest structural attributes, such as tree height, DBH, and stem volume, remotely [34,41-43]. Although extensive work has been undertaken in forestry [44], applications of SfM-MVS in coastal environments are limited [45-47]. Only one study at the time of writing has used UAV-derived SfM-MVS to estimate AGB in mangroves, however, only the upper canopy was observed [43]. It is unknown how well this technique captures forest structure below the canopy in mangrove ecosystems when compared with a more established ground-based survey method, such as TLS.

The objective of this study is to assess the efficacy of using SfM-MVS for capturing forest structure in three mangrove sites with differing structural characteristics. Given applications of SfM-MVS have been mainly conducted in forestry plantations characterized by tree stands of regular height and spacing, we were interested to see how this method would perform in mangroves, which have more peculiar growth form. Comparisons of point cloud utility is made between SfM-MVS and TLS, and canopy height models (CHMs) are generated to estimate forest volume as a proxy for AGB. The findings of this study can be used to inform future applications of the SfM-MVS technique and whether it is viable for capturing detailed mangrove forest structure to inform AGB estimations. 


\section{Materials and Methods}

\subsection{Study Area}

Noosa Heads is a small coastal town located roughly $100 \mathrm{~km}$ north of Brisbane, Queensland. The region is sub-tropical, experiencing $\sim 1400 \mathrm{~mm}$ precipitation per year, mostly during November to March [48]. The town is bounded to the north by the Noosa River, a complex river system that originates near Mount Elliot and extends $\sim 74 \mathrm{~km}$ south-east before entering the Pacific Ocean between Noosa Heads and the southern tip of the Great Sandy National Park (Figure 1). The study area is located within the Weyba Creek Conservation Park between Lake Weyba and the Noosa River estuary (Figure 1).
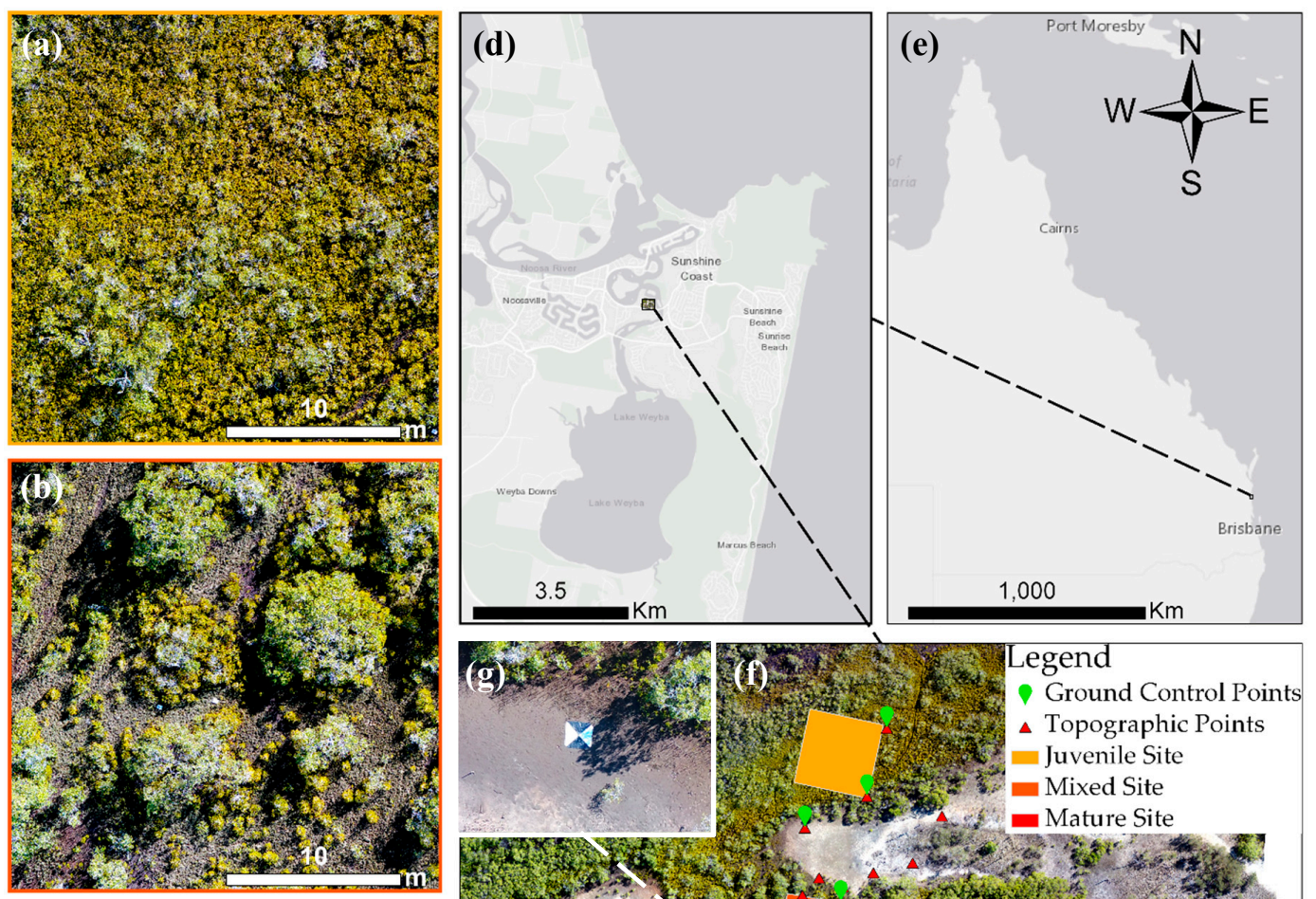

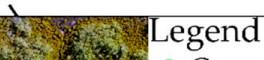
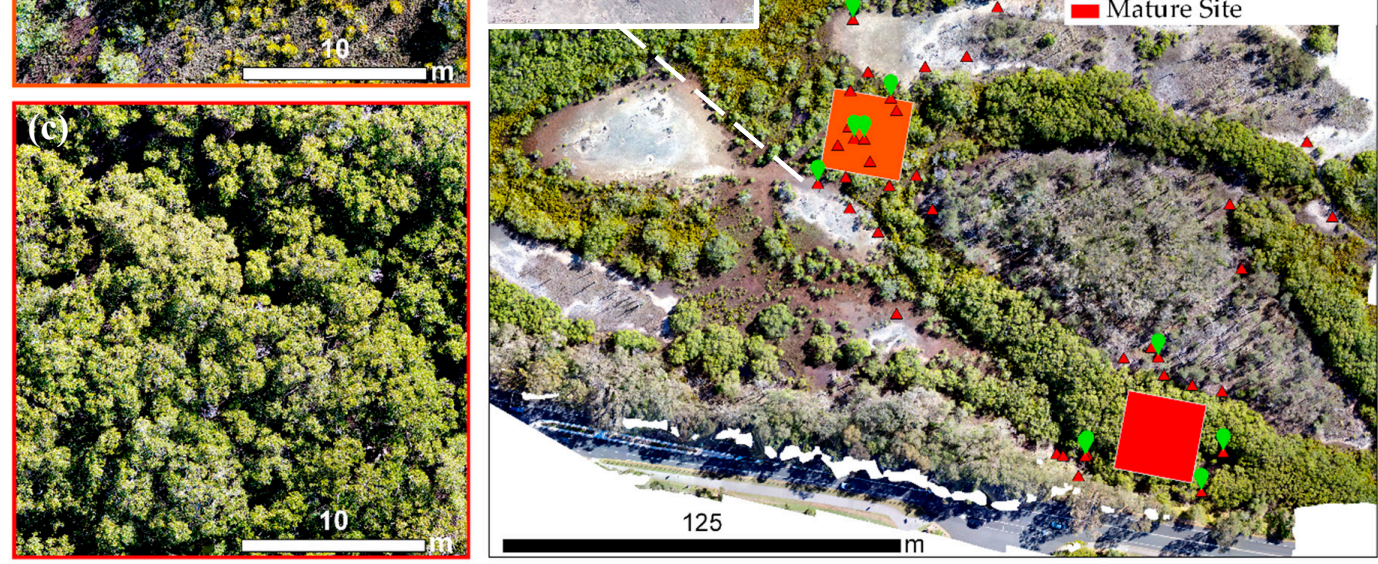

Figure 1. Aerial views of the (a) juvenile, (b) mixed, and (c) mature sites, geographic location in relation to the (d) Noosa River system and (e) greater Queensland, (f) location of sites and survey points in study area, and (g) example of a black and white marker.

\subsection{Survey Sites}

Three $25 \times 25 \mathrm{~m}$ sites were delineated on the 15 August 2018 to capture the structural attributes associated with increasing stand age and included: (a) 'Juveniles': Mostly seedlings and juveniles $<1.37 \mathrm{~m}$ tall with some mature individuals; (b) 'mixed': Individuals of varying age; and (c) 'mature': Mostly mature age individuals $>2.5 \mathrm{~m}$ (Figure 1). Field characterization was conducted using 
an inclinometer to obtain tree heights, and mangrove species were identified using descriptions from [49]. The juvenile site was dominated by a dense population of juvenile Aegicerus corniculatum (River Mangrove) ranging from 0.7 to $1.5 \mathrm{~m}$ tall with scattered Avicennia marina var. australasica (Grey Mangrove) at around $3.5 \mathrm{~m}$ tall. The mixed site contained the same species, but was less dense, with larger spacings between individual A. marina var. australasica trees and scattered juvenile A. corniculatum shrubs growing at similar heights as the juvenile site. This site also had a thick matting of Sporobolus virgincus (Saltcouch) covering the ground surface. The mature site was dominated by mature age A. marina var. australasica trees growing up to around $8 \mathrm{~m}$ tall with a dense canopy and ground surface covered by pneumatophore roots.

\subsection{Field Surveys}

A CHC X91+ Real-Time-Kinetic GNSS (RTK-GNSS), which has a horizontal and vertical precision of up to $8 \mathrm{~mm}$ and $15 \mathrm{~mm}$, respectively [50], was used to obtain 45 Topographic Points (Figure 1). From these points, 11 ground control points were chosen near the borders of each site, and these positions were flagged using black and white markers, so they were visible in the subsequent UAV survey (Figure 1).

A consumer-grade DJI Phantom 4 Advanced quadcopter was used to obtain 591 overlapping images of the entire study site. The drone was mounted with a 1" CMOS (complementary metal-oxide semiconductor) sensor, with an effective pixel size of 20 megapixels, and images were taken at a resolution of $5472 \times 3648$ in the RGB (red-green-blue) spectrum using the FC6310 camera $(8.8 \mathrm{~mm})$ [51]. The Ground Station Pro App (DJI, version 2.0) was used to plan the flight, which utilised an orthogonal flight path and image overlap of $90 \%$ forward and $60 \%$ side overlap (Figure 2). The flight was conducted at an average of $51.6 \mathrm{~m}$ above ground level, which resulted in a ground sampling distance (GSD) of $1.38 \mathrm{~cm}$ per pixel over an area of $0.07 \mathrm{~km}^{2}$. We used automatic take-off and landing for the flight, which took $20 \mathrm{~min}$ and was conducted at $0830 \mathrm{~h}$ Australian Eastern Standard Time (AEST) on the 30 August 2018, with fine weather and light winds.

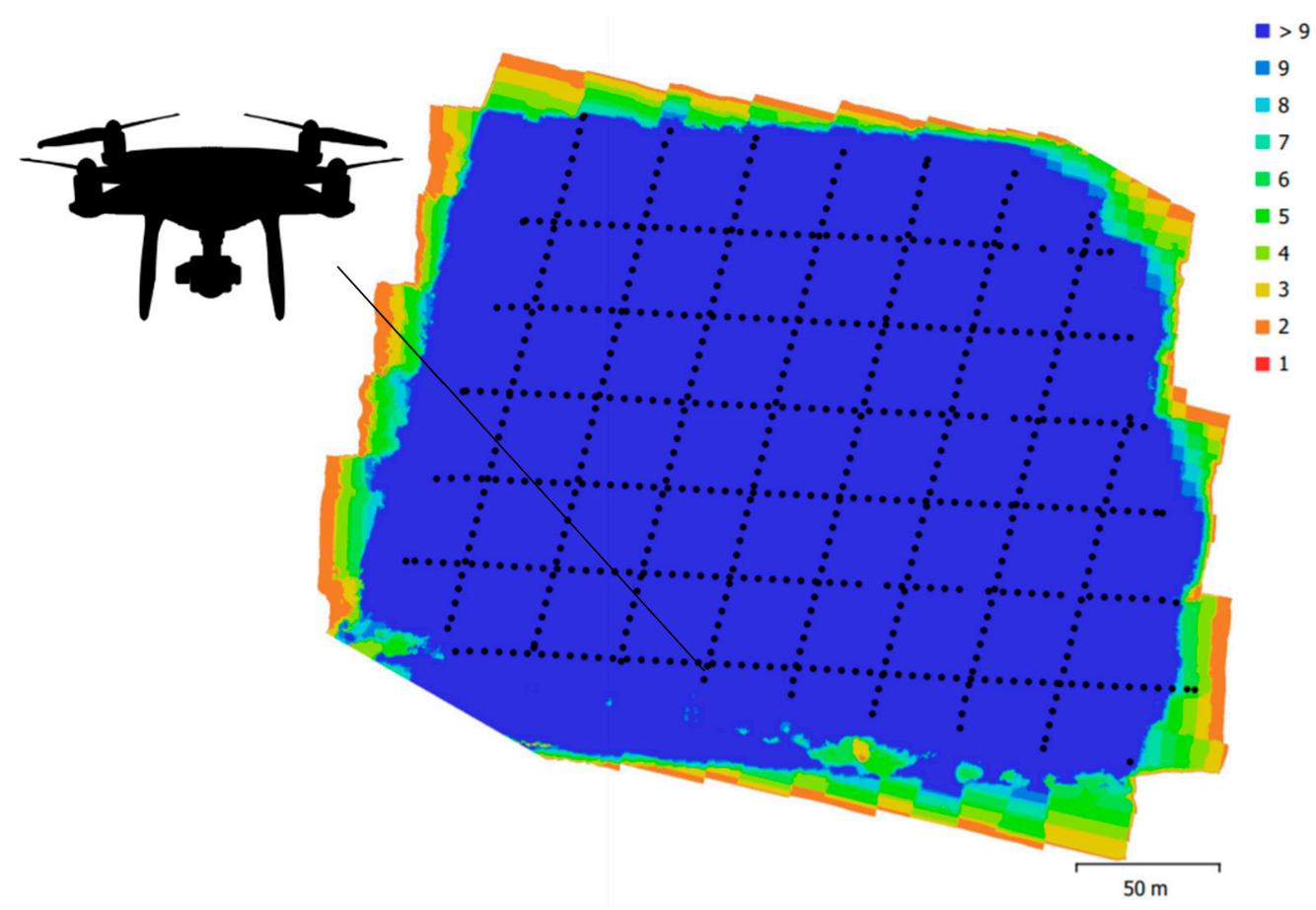

Figure 2. DJI Phantom 4 Advanced quadcopter and flying pattern indicating the number of overlapping images, obtained from Agisoft PhotoScan (version 1.5.0). 
We used a Faro Focus ${ }^{3 D}$ S 120 TLS scanner, which projects constant infrared waves of differing length outward until they contact an object and are reflected back. Distance is measured by detecting phase shifts in the infrared waves, and Cartesian coordinates $(x, y, z)$ are recorded. The ranging unit is capable of capturing points up to $120 \mathrm{~m}$ away, with a ranging error of $\pm 2 \mathrm{~mm}$ within $25 \mathrm{~m}$ using the factory defined settings. We used a multi-scan approach to capture the forest structure in each site (Figure $3 \mathrm{a}-\mathrm{c}$ ). To co-register individual scans into a single point cloud, we used a minimum of three spheres or checkerboard targets in each scan. Targets were placed in open areas to allow the best possible visibility (Figure 3d,e). The number of scans required per site was determined in the field, which was dependent on the characteristics of the site and the visibility of the targets. For example, seven scans were required in the juvenile site, where dense understory vegetation blocked direct sight between some targets, whereas the mature site only required six scans as targets were easily visible. All scans were conducted in fine weather, however, when scanning the juvenile site, wind gusts up to 19 knots were recorded nearby.

(a)

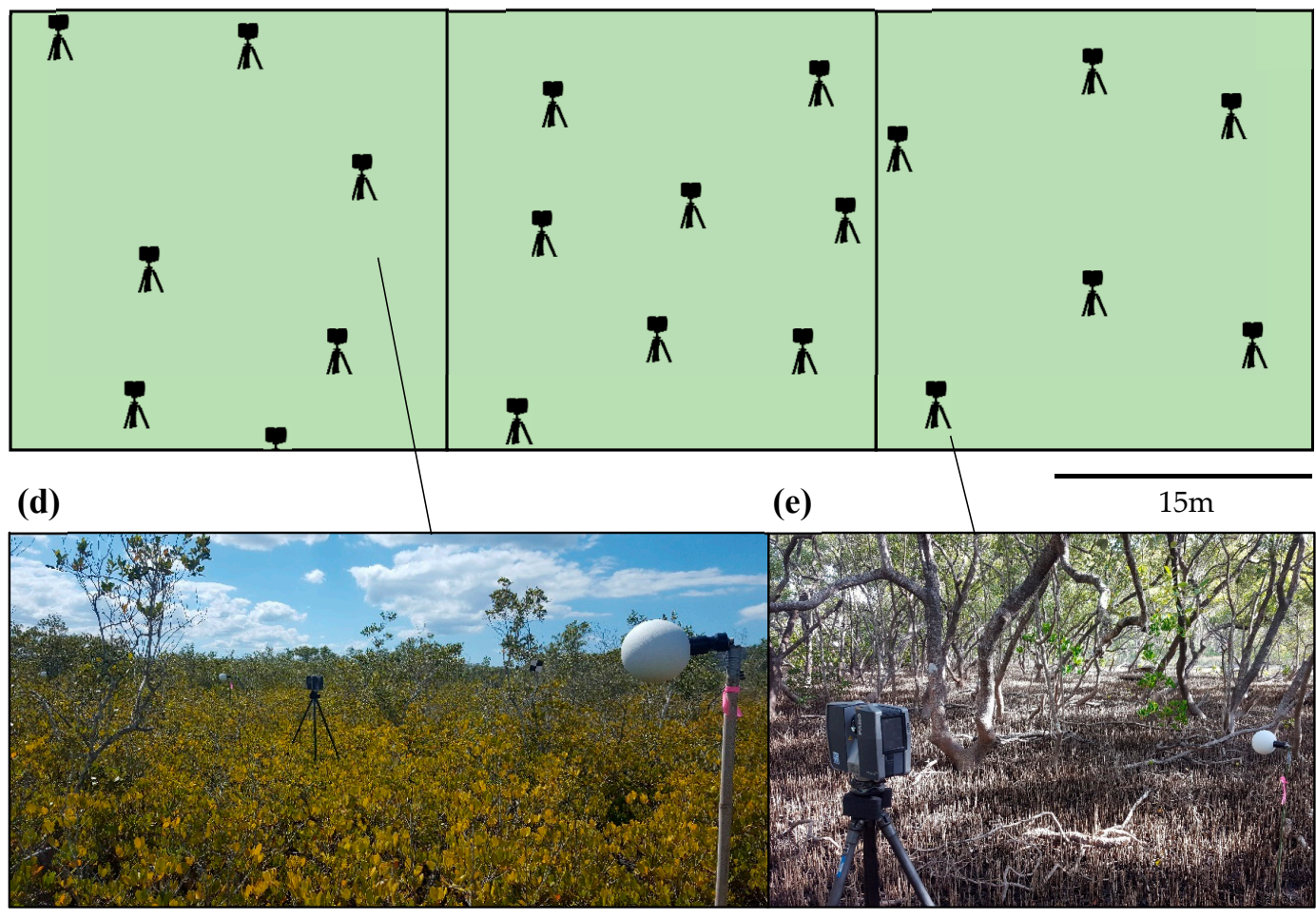

Figure 3. Locations of terrestrial laser scanning locations for (a) Juvenile, (b) mixed, and (c) mature sites; (d) checkerboard and sphere targets in the juvenile site; and (e) the TLS scanner alongside the sphere target in the mature site.

\subsection{Data Processing}

The UAV and TLS field surveys were uploaded to the relevant software to process the point cloud data (Figure 4).

The UAV data was uploaded into Agisoft Photoscan Professional (version 1.4.3, 64-bit) and was batch processed at 'high quality'. The model used all 591 images to create a dense point cloud using automatic mesh reconstruction. The model was georeferenced in PhotoScan to the Geocentric Datum of Australia (GDA) 1994 Map Grid of Australia (MGA) Zone 56 using the 11 GCP points, and the batch process was re-run after camera optimization (non-linear corrections). The TLS data was imported into FARO Scene (version 5.3) for pre-processing and point cloud registration. Target spheres were identified in the hemispherical photos and given the corresponding Universal Transverse Mercator (UTM) coordinates in the GDA 94 MGA Zone 56 reference system, which were obtained by offsetting 
from GCPs surveyed with the RTK-GNSS. Checkerboard targets were used to co-register individual scans into a single point cloud for each site using the default origin $(0,0,0)$ in Faro SCENE (v5.3). The TLS point clouds were clipped to a $625 \mathrm{~m}^{2}$ area using a virtual bounding box and both the SfM-MVS and TLS point clouds were imported into CloudCompare (v2.10. alpha, 64 bit) for rasterization.

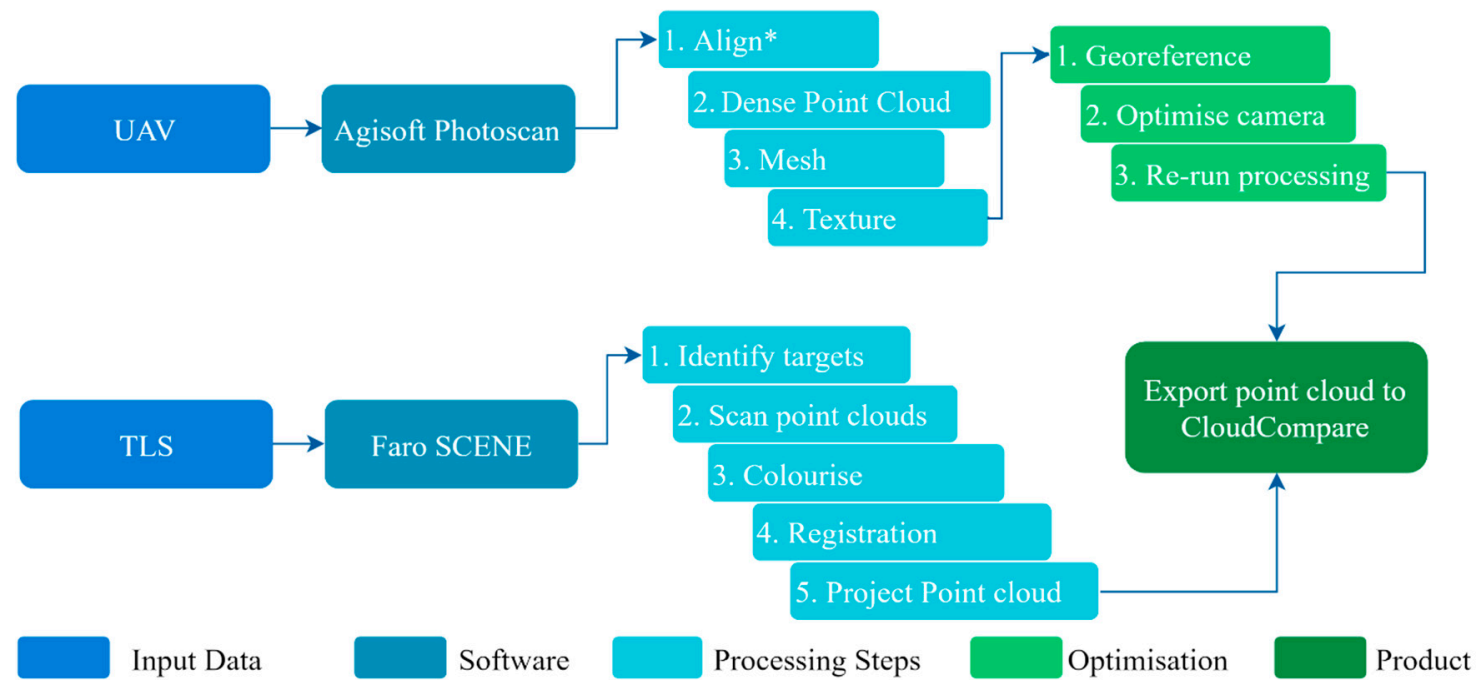

Figure 4. Data processing for UAV and TLS surveys, including software used, processing steps, optimization, and final product. * Indicates beginning of structure-from-motion multi-view stereo processing.

The point clouds were segmented using a single transect across each site for both methods to examine profile point densities and canopy penetration. All point clouds were converted to a digital surface model (DSM) using the 'Rasterize' tool in CloudCompare using the maximum z values and a cell resolution of $3 \mathrm{~cm}^{2}$, with eight DSMs created in total. Two DSMs were created from the SfM-MVS survey that spanned the entire study site, and six DSMs were created from the TLS survey that were confined to the $625 \mathrm{~m}^{2}$ area of each mangrove site. Half of the created DSMs had empty cells interpolated using the average height value, while the other half were not interpolated. This allowed an estimation of coverage by dividing the empty cell DSM by the interpolated DSM and multiplying by 100 .

\subsection{Volume Calculation}

A volumetric or surface differencing approach was used to estimate mangrove forest volume, which involves subtracting a DTM from a DSM to obtain a CHM, thereby normalizing object heights above ground [52]. Forest volume, which includes all pixels associated with aboveground vegetation, can then be estimated by multiplying the canopy height value of a raster cell by its resolution $[53,54]$. A DTM was created in ArcMap (version 10.6) by interpolating all 45 topographic points with the 'Topo to Raster' tool (Figure 5).

In ArcMap, the SfM-MVS DSM was projected to the GDA 94 MGA Zone 56 reference system and the Australian Height Datum (AHD). The TLS DSMs were imported with $z$ elevation, but no $x$ or y coordinates, due to a truncation issue with the global coordinates in FARO Scene. Therefore, the TLS DSMs were also projected into the GDA 94 MGA Zone 56 and AHD reference systems, and subsequently georeferenced to the same coordinates as the SfM-MVS DSMs manually in ArcMap. During the rasterisation process, it was noted that some point clouds contained spurious points below ground height, which carried over into the raster model. Therefore, these were corrected using a conditional raster that changed their value to zero. Once the per cell volume was calculated, the sum of all cells contained within each site gave the estimated forest volume in cubic metres $\left(\mathrm{m}^{3}\right)$. 


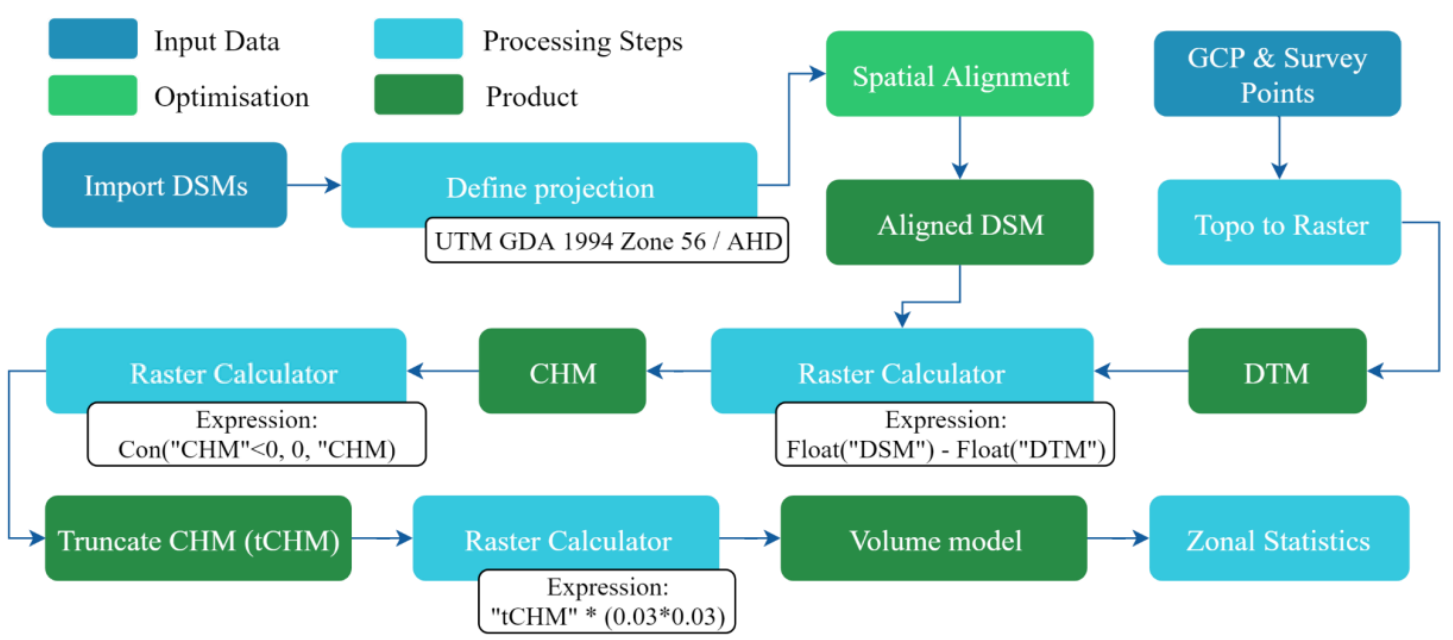

Figure 5. Volume calculation workflow conducted in ArcMap. Note this workflow was repeated for both SfM-MVS and TLS across all three sites, making six iterations in total.

The raster models were converted to point files and the mean absolute error (MAE) for canopy height models and volume estimations were calculated using the equation:

$$
\text { MAE }=\frac{1}{n} \sum_{j=n}^{n}\left|y_{j}-\hat{y}_{j}\right|
$$

where $n$ is the number of observations, $y_{j}$ is the observed value, and $\hat{y}_{j}$ is the predicted value calculated for each observation.

The differences in volume were also expressed as a percentage using the equation:

$$
\text { Percentage difference }=100^{*} \mid T L S-S f M-M V S /((T L S+S f M-M V S) / 2)
$$

Finally, the CHMs were reclassified so that only vegetation greater than $1.37 \mathrm{~m}$ was displayed, which produced a rough estimate of canopy cover. The SfM-MVS volume raster was subtracted from the TLS volume raster to identify the spatial distribution of differences in forest volume.

\section{Results}

\subsection{Point Clouds}

The point cloud derived from the SfM-MVS process can be seen in Figure 6.

The SfM point matching used 336,195 tie points to create a sparse point cloud, which was increased to $162,196,895$ points using MVS over an area of $67,292.19 \mathrm{~m}^{2}$, with white pixels indicating areas of no data (Figure 6). The side view of the SfM-MVS revealed spurious low points that were most evident in the eastern side of the study area (Figure 6). A side profile view of the TLS surveys indicates high point density in understory vegetation, with some gaps evident in the canopy, especially in the mature site (Figure 7). Spurious low points were also evident in the TLS scans, especially in the mature site (Figure 7). 
(a)

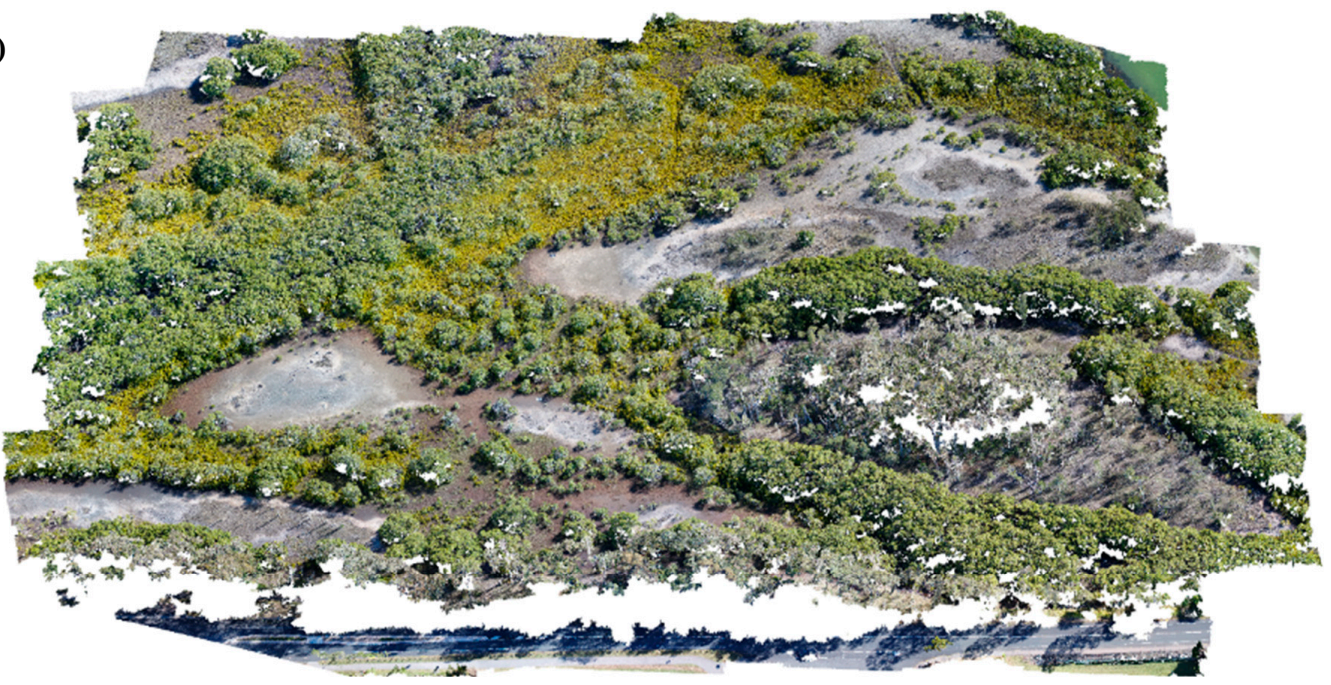

(b)

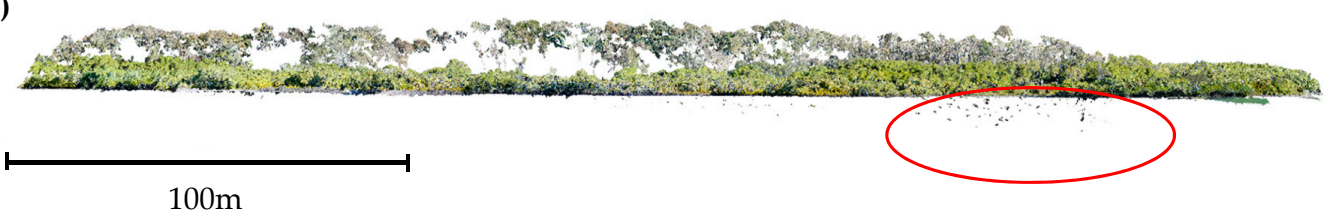

Figure 6. Point cloud of the entire study area derived from high resolution unmanned aerial vehicle imagery and SfM-MVS processing viewed from (a) an aerial angle and (b) a horizontal angle. Note the red circle indicates spurious low points.

(a)
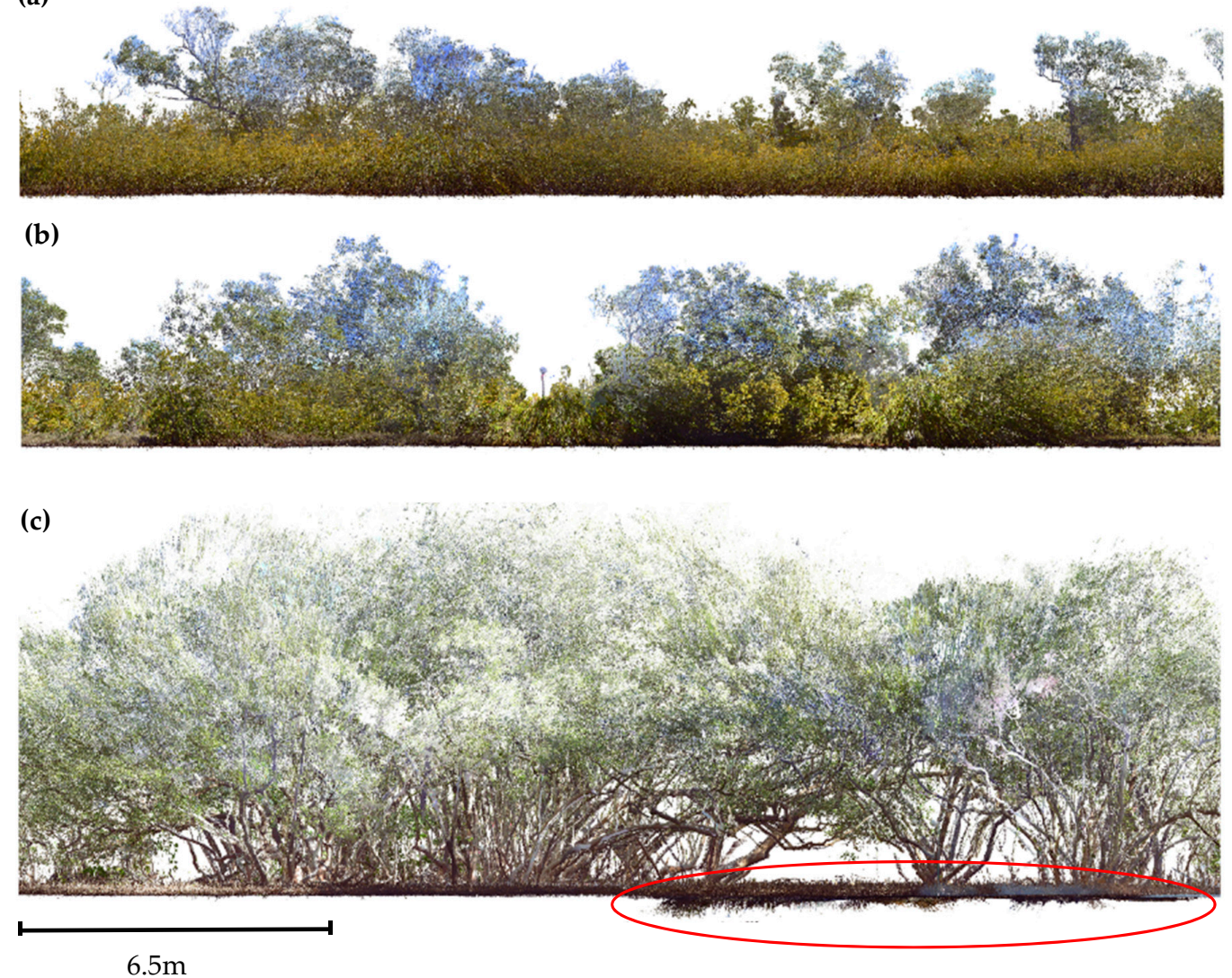

Figure 7. Horizontal profile of TLS point clouds for (a) juvenile, (b) mixed, and (c) mature sites. Note the red circle indicates spurious low points. 
A comparison of methods in terms of survey and processing time can be seen in Table 1.

Table 1. Time required for surveys and data processing and number of points per $625 \mathrm{~m}^{2}$.

\begin{tabular}{|c|c|c|c|c|}
\hline & \multirow{2}{*}{$\begin{array}{l}\text { SfM-MVS } \\
\text { Study Area }\end{array}$} & \multicolumn{3}{|c|}{ TLS } \\
\hline & & Juvenile & Mixed & Mature \\
\hline No. of scans & 1 & 7 & 8 & 6 \\
\hline Survey time & $20 \mathrm{~min}$ & $3.5 \mathrm{~h}$ & $3 \mathrm{~h}$ & $2.5 \mathrm{~h}$ \\
\hline Processing time $^{1}$ & $37 \mathrm{~h}$ & $2 \mathrm{~h}$ & $1.5 \mathrm{~h}$ & $1.5 \mathrm{~h}$ \\
\hline Points per $625 \mathrm{~m}^{2}$ & $1,506,426$ & $66,520,190$ & $121,085,632$ & $147,995,632$ \\
\hline
\end{tabular}

Computer specifications: Laptop: Dell Precision 5520 i7-7820HQ CPU @ 2.90 GHz 32 GB RAM, Graphics Processing Unit (GPU) Quadro M1200

* Note all times are approximate. ${ }^{1}$ Processing time includes time spent co-registering scans manually for TLS, which took longer in the juvenile site due to dense vegetation.

Survey time was lower for the SfM-MVS than the TLS surveys, with all data collected by the UAV in roughly $20 \mathrm{~min}$ (Table 1). The final point clouds for the TLS produced up to $\sim 100$ times more points compared to SfM-MVS, with the highest and lowest number of points recorded in the mature and juvenile sites, respectively (Table 1). More scans did not necessarily correspond to more registered points, as the mature site had the most points, but fewest scans (Table 1). Scanning coverage differed between all sites as seen in Figure 8.
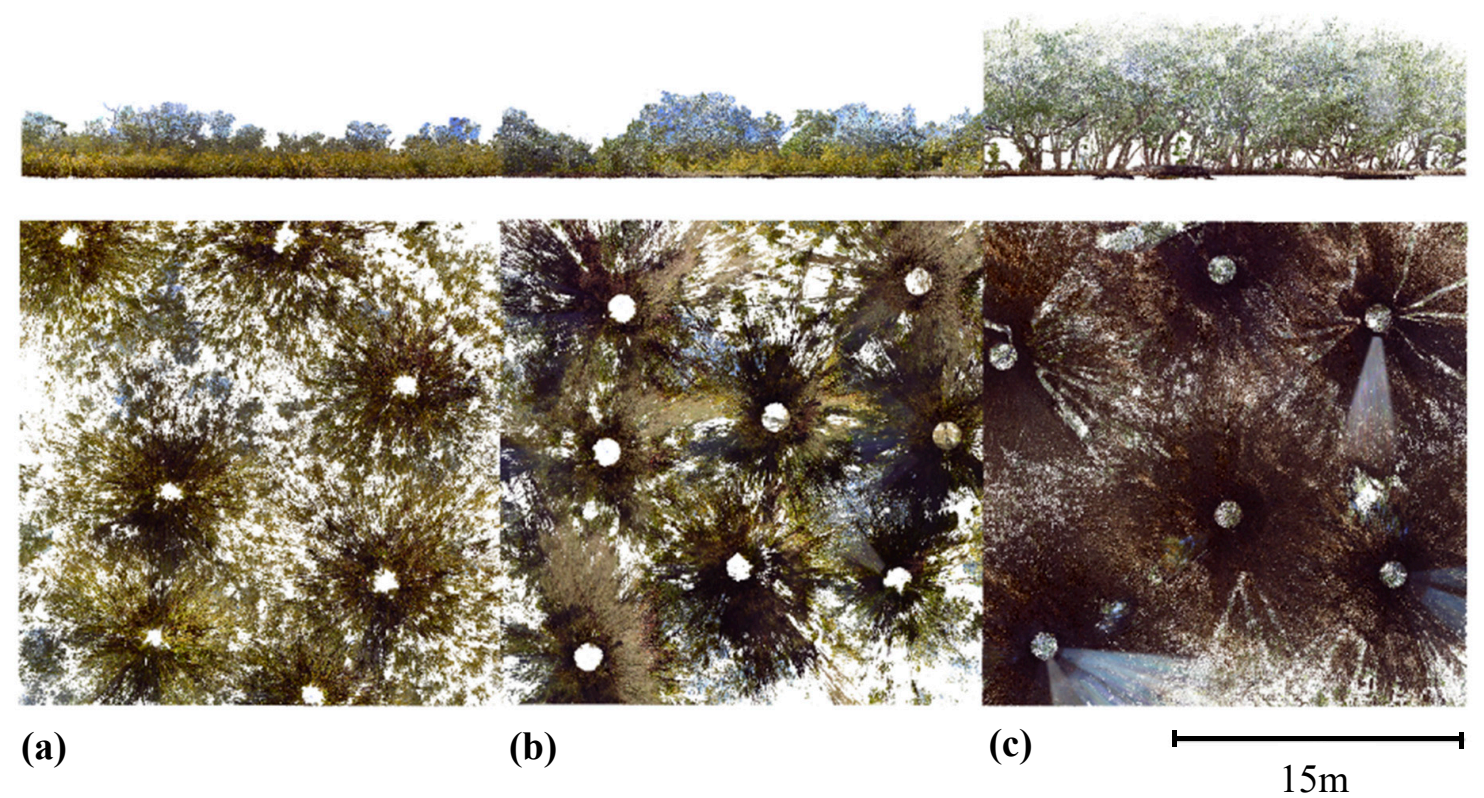

Figure 8. Coverage for different scanner positions from the TLS surveys using a 'bottom up' view in the (a) juvenile, (b) mixed, and (c) mature sites.

Fewer empty cells were visible in the mature site compared to the juvenile and mixed sites, resulting in greater overall coverage (Figure 8). The results of the point cloud rasterization and coverage calculations can be seen in Table 2.

The lowest and highest cell coverage occurred for the TLS scans in the juvenile and mature sites, respectively (Table 2). The SfM-MVS method produced less variation in cell coverage compared to the TLS (Table 2). Profiles derived from segments of the point clouds can be seen in Figure 9. 
Table 2. Summary of the rasterization process.

\begin{tabular}{|c|c|c|c|c|c|c|}
\hline & \multicolumn{3}{|c|}{ TLS } & \multicolumn{3}{|c|}{ SfM-MVS } \\
\hline & Juvenile & Mixed & Mature & Juvenile & Mixed & Mature \\
\hline Area $\left(\mathrm{m}^{2}\right)^{1}$ & 620.75 & 633.33 & 621.24 & 619.81 & 633.34 & 621.24 \\
\hline No. of cells (no interpolation) ${ }^{2}$ & 506,264 & 587,899 & 680,271 & 630,627 & 652,552 & 592,796 \\
\hline No. of cells (interpolation) ${ }^{3}$ & 689,726 & 703,702 & 690,263 & 688,673 & 703,705 & 690,266 \\
\hline Coverage $(\%)$ & 73.40 & 83.54 & 98.55 & 91.57 & 92.73 & 85.88 \\
\hline
\end{tabular}

$1,2,3$ Note slight differentiation in site boundaries led to differences in the total area and cell numbers for each site, as noted above.

Tree stems, foliage, and the ground surface were well represented in the mature site (Figure 9). Point densities appear to decrease within dense vegetation across all sites, including the TOC and at ground level (Figure 9). Ground points were under-represented using the SfM-MVS method, including areas below dense vegetation or canopy (Figure 9). It was also noted that the TLS registered several points in 'mid-air' that were not captured by the SfM-MVS method, which was most evident in the juvenile and mixed sites (Figure 9).
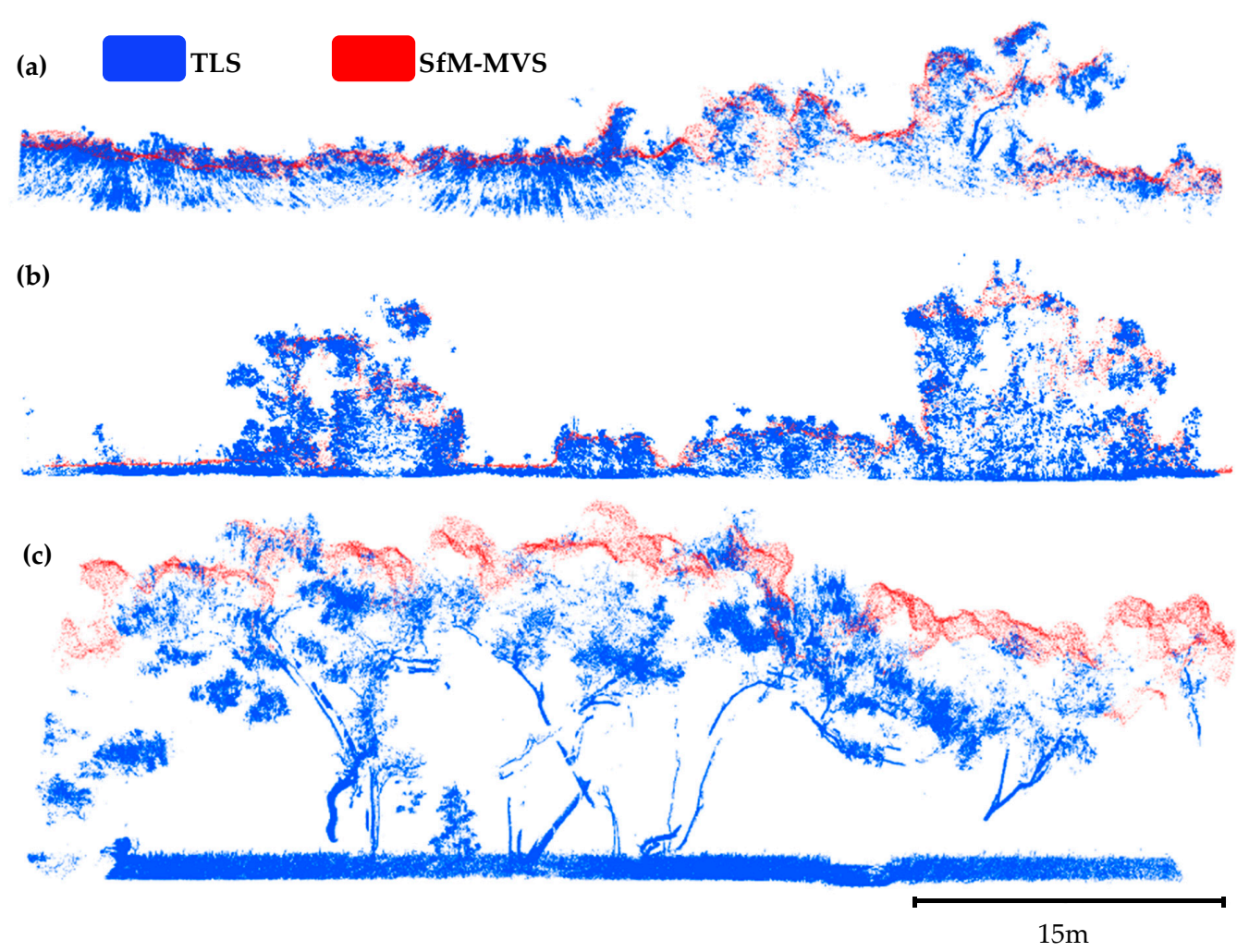

Figure 9. Horizontal profile of point clouds compared between methods and (a) juvenile, (b) mixed, and (c) mature sites.

\subsection{Forest Volume}

The SfM-MVS method produced lower maximum cell heights than TLS for all sites after rasterization (Table 3).

The average maximum heights were lower for the SfM-MVS method in the juvenile and mixed sites, and higher in the mature site when compared with TLS (Table 3). This corresponded to lower measures of volume in the juvenile and mixed sites, but higher volume in the mature site for SfM-MVS (Table 3). The error calculated between the methods for canopy height and volume estimates can be seen in Table 4. 
Table 3. Descriptive statistics for digital surface models across sites and survey methods.

\begin{tabular}{ccccccc}
\hline & \multicolumn{3}{c}{ TLS } & \multicolumn{3}{c}{ SfM-MVS } \\
\cline { 2 - 7 } & Juvenile & Mixed & Mature & Juvenile & Mixed & Mature \\
\hline Max height (m) & 3.88 & 4.70 & 8.66 & 3.45 & 4.01 & 8.27 \\
Avg. max. height (m) & 1.09 & 0.94 & 4.51 & 0.71 & 0.71 & 5.11 \\
(Std. Dev.) & $(0.52)$ & $(0.91)$ & $(2.11)$ & $(0.57)$ & $(0.93)$ & $(1.75)$ \\
Volume ${\left(\mathbf{m}^{3}\right.}^{\mathbf{3}}$ & 679 & 596 & 2800 & 439 & 448 & 3180 \\
\hline
\end{tabular}

The highest MAEs for both the CHM and volume estimation were observed in the mature site, and the lowest were observed in the mixed site (Table 4). The lowest percentage difference in volume was recorded in the mature site, despite having the greatest error (Table 4). The highest percentage difference in volume was recorded in the juvenile site, with the mixed site also reporting a substantial difference in volume estimation (Table 4). The TLS-derived canopy cover was $20.03 \%$ in the juvenile site, $30.91 \%$ in the mixed site, and $84.15 \%$ in the mature site (Figure 10a-c).

Table 4. Mean absolute error and percentage difference between TLS and SfM-MVS.

\begin{tabular}{cccc}
\hline & Juvenile & Mixed & Mature \\
\hline CHM-MAE & $0.39 \mathrm{~m}$ & $0.23 \mathrm{~m}$ & $0.61 \mathrm{~m}$ \\
Volume-MAE & $3.47 \times 10^{-4} \mathrm{~m}^{3}$ & $2.10 \times 10^{-4} \mathrm{~m}^{3}$ & $5.50 \times 10^{-4} \mathrm{~m}^{3}$ \\
Volume-Percent diff. ${ }^{1}$ & $42.95 \%$ & $28.23 \%$ & $12.72 \%$ \\
\hline
\end{tabular}

${ }^{1}$ Note percent difference was calculated as the deviation of SfM-MVS from TLS measurements.

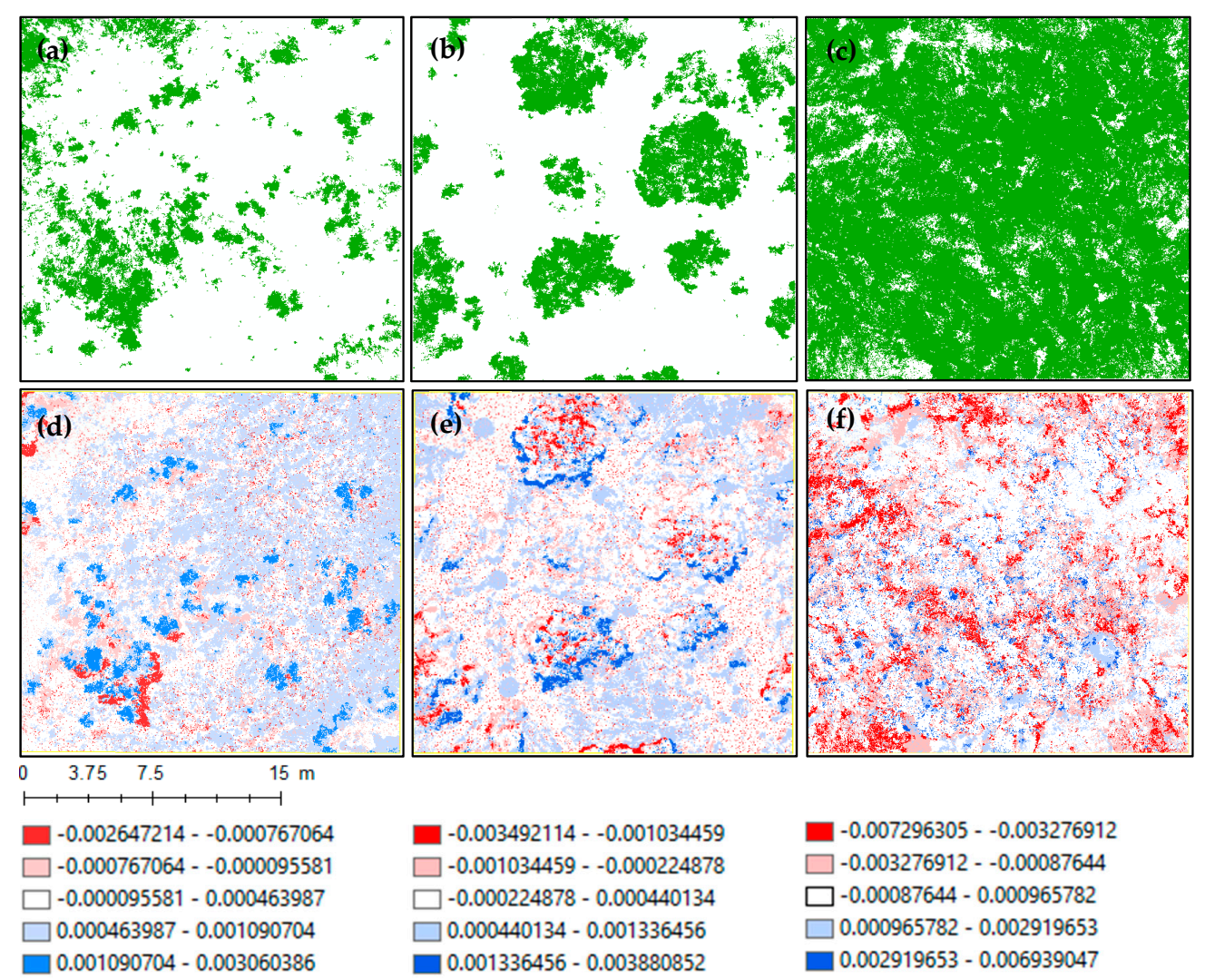

Figure 10. Canopy cover as measured by the TLS for the (a) juvenile, (b) mixed, and (c) mature site, and volume differences in the (d) juvenile, (e) mixed, and (f) mature site. Note blue colours indicate higher TLS estimates while red indicates lower TLS estimates when compared to SfM-MVS. 
Differences in volume between the juvenile, mixed, and mature sites can be seen in Figure $10 \mathrm{~d}-\mathrm{f}$. The TLS produced greater measures of volume for vegetation below $1.37 \mathrm{~m}$, as indicated by the prevalence of blue cells in those sites (Figure 10d,e). In the mature site, the greatest volume differences generally corresponded to canopy gaps, with the SfM-MVS recording greater heights in these areas compared to the TLS (Figure 10f).

\section{Discussion}

\subsection{Point Cloud Density and Forest Structure}

In general, the UAV point cloud was obtained much faster than the TLS point clouds, and despite having a greater overall processing time, much of this was automated and required little input, which was comparable with other studies $[28,46]$. The time taken to conduct traditional AGB assessments in mangroves is not often reported, however, survey periods generally extend across several months depending on the size and complexity of the site. This is generally related to the muddy and/or inaccessible terrain and the desire to minimise damage from trampling pneumatophore roots and seedlings [11]. By comparison, the 20-minute UAV flight or multi-day survey conducted with the TLS in this study required substantially less time in the field compared to traditional methods. The final TLS point clouds contained approximately 45 to 100 times more points per/625 $\mathrm{m}^{2}$ than the SfM-MVS point clouds across all sites. Point density of this magnitude is not uncommon using TLS [26,53], and the lower point density for SfM-MVS is likely linked to the survey settings. For example, flying at a lower altitude or increasing the degree of image overlap can greatly increase point density [55]. However, it should be considered whether the greater point density offered by the TLS is worth spending more time in the field, increasing the potential of trampling damage.

High stem density in the juvenile site likely led to poor cell coverage and capture of forest structure, whereas a low stem density in the mature site allowed greater capture of forest structure. Occlusion is a commonly reported limitation of using TLS in vegetated environments [56], which can lead to highly variable point densities $[23,28,57,58]$. This was partially controlled for by incorporating multiple scans well within the optimal $25 \mathrm{~m}$ radius from the scanner, however, laser pulses were still unable to penetrate fully through dense vegetation. The higher average cell coverage for SfM-MVS was likely due to the high redundancy of overlapping images, which ensures sufficient point matching $[46,55]$, and the high spatial resolution of the imagery. Despite this, the SfM-MVS method only captured the outer canopy envelope, with many studies linking poor canopy penetration to low capture of forest structure and/or underlying terrain [39,59-61]. As expected, the ground-based TLS was better able to capture below canopy forest structure, whereas the aerial-based SfM-MVS was better equipped to survey canopy height, with neither survey type efficient for both.

\subsection{Canopy Height and Volume Estimations}

The higher average maximum canopy height for SfM-MVS in the mature site is likely due to overestimation, which has been found in mangroves [43] and other forested environments [28,39,59,61]. SfM-MVS is generally unable to represent fine scale canopy gaps [62] and smoothing of these gaps during rasterization can lead to overestimations of height [23]. This was observed in the volume difference raster, where greater SfM-MVS volumes tend to correspond to gaps in the canopy cover. Furthermore, the lower maximum cell height recorded by SfM-MVS in this site is not unusual, as this method is known to underestimate the maximum height of individual plants [55]. The higher error recorded in this site, despite having the lowest difference in volume, is likely due to poor TOC representation for the TLS, which had the highest standard deviation for all sites. Occlusion of TOC points in TLS scans can produce erroneous canopy height estimations [63], with a low TOC sample point density corresponding to under-estimations of canopy height in other studies [18]. It is important to note all AGB estimations carry some degree of error. For example, the departure of allometric models, which are generally considered more robust, from measured field data has been reported as 
high as $49.2 \%$ for estimations of AGB [20], and 18.4\% for estimations of volume [64] in mangroves, which varies between the species and equations used.

Conversely, the average maximum canopy height was lower for the juvenile and mixed sites, which also had high variation between volume estimations. This was likely a function of the dense understory layer in the juvenile site, as high stem density can lead to poor point capture for both SfM-MVS [65] and TLS [23]. For the TLS measurements, greater recorded heights and subsequent volume may be a function of artificial mid-air points that result from beam interceptions at the canopy edge, which can affect height estimations $[28,56]$. In this case, beam interceptions may have occurred horizontally, where taller shrubs occluded shorter ones, producing spurious high points. For the SfM-MVS, it is possible that high stem density led to poor image matching, which can lead to underestimations of DSM heights [32]. Alternatively, wind gusts can cause outer branches to move between images, leading to feature rejection during image matching [55], which would explain the poor representation of higher points by SfM-MVS in the juvenile site. Similar effects may have occurred in the mixed site, however, the difference in error and volume were likely reduced due to decreased stem density. For example, SfM-MVS is more likely to match LiDAR data in sparsely vegetated areas $[65,66]$, and error decreases with increasing bare area [67]. Similarly, occlusion is less of an issue for TLS scans in sparsely vegetated environments [58]. The greatest differences between SfM-MVS and TLS in this site occurred in the TOC and at the canopy edge, which suggests occlusion and beam interceptions may have hindered point capture in these dense areas.

\subsection{Limitations and Future Considerations}

Comparison between the canopy cover raster and the volume difference raster highlighted horizontal misalignments between the TLS and SfM-MVS raster models. This was greatest in the juvenile and mixed sites, where canopy edges tend to 'shadow' each other. This is an artefact of the georeferencing process, which had to be performed manually in ArcMap. Horizontal co-registration error for canopy heights are generally small [68], but vertical co-registration of CHMs and DTMs obtained from different data sources remains a major challenge when estimating canopy heights [55]. In this case, DSMs and DTMs were aligned vertically using the AHD projection, but models were imperfectly aligned horizontally, which may have led to differences in volume estimations. Differences may have also stemmed from spurious high points as mentioned previously. This could likely be resolved by using a point filtering algorithm to remove outliers, or by using a percentile of a cell's elevation rather than the maximum $z$ value, as this can make CHMs less sensitive to outliers $[39,66]$.

The surface differencing method requires an accurate high spatial resolution DTM to normalize canopy heights above ground [23,69]. The DTM created in this study interpolated elevation heights that were taken at the peripheries of each site, since the RTK-GNSS could not obtain a signal below the canopy. This is less of an issue in small level plots, as changes in topography are expected to be minimal [28]. However, any upscaling of this method would require a more representative DTM. The surface differencing method also assumes a constant volume below the height of the CHM [53]. Each site contained mangrove species with different growth forms at differing stem densities. Furthermore, wood density in mangroves is species-specific [11,12], meaning the AGB across each site is not constant and will differ depending on the species composition. Therefore, sites that contain a higher stem density that are dominated by a single species, such as the juvenile site, likely represent a more accurate estimation of volume using this method.

\section{Conclusions}

This study compared the ability of SfM-MVS and TLS to capture forest structure and volume in three mangrove sites of differing structural characteristics. For forest structure, SfM-MVS was unable to capture points below the canopy in the same detail offered by TLS, which was clearly superior in terms of point density. For forest volume, SfM-MVS captured the top of the canopy more accurately than the TLS, which suffered from occlusion, however, it tends to overestimate volume in canopy gaps. 
Furthermore, increasing stem density led to the capture of erroneous points for both SfM-MVS and TLS, suggesting either method may be more appropriate in lower density mangroves.

In summary, we suggest TLS would be more beneficial for capturing mangrove forest structure, whereas SfM-MVS would be better for capturing mangrove canopy height, and subsequent volume. However, the choice between either SfM-MVS and TLS depends on the accuracy, spatial scale, and time scale required, with both offering potential advantages and disadvantages. Our results could better inform future work in the conservation of these important ecosystems, given the rapid decline of mangroves globally.

Author Contributions: All work conducted by A.D.W. and J.X.L.

Funding: This research received no external funding.

Acknowledgments: We would like to acknowledge the School of Science and Engineering at the University of the Sunshine Coast, Queensland, for supporting our research.

Conflicts of Interest: The authors declare no conflict of interest.

\section{References}

1. Giri, C.; Ochieng, E.; Tieszen, L.L.; Zhu, Z.; Singh, A.; Loveland, T.; Masek, J.; Duke, N. Status and distribution of mangrove forests of the world using earth observation satellite data. Glob. Ecol. Biogeogr. 2011, 20, 154-159. [CrossRef]

2. Mackenzie, J.R.; Duke, N.C.; Wood, A.L. The Shoreline Video Assessment Method (S-VAM): Using dynamic hyperlapse image acquisition to evaluate shoreline mangrove forest structure, values, degradation and threats. Mar. Pollut. Bull. 2016, 109, 751-763. [CrossRef]

3. Cuc, N.T.K.; Suzuki, T.; de Ruyter van Steveninck, E.D.; Hai, H. Modelling the Impacts of Mangrove Vegetation Structure on Wave Dissipation in Ben Tre Province, Vietnam, under Different Climate Change Scenarios. J. Coast. Res. 2015, 31, 340-347. [CrossRef]

4. Thomas, N.; Bunting, P.; Lucas, R.; Hardy, A.; Rosenqvist, A.; Fatoyinbo, T. Mapping Mangrove Extent and Change: A Globally Applicable Approach. Remote Sens. 2018, 10, 1466. [CrossRef]

5. Donato, D.C.; Kauffman, J.B.; Murdiyarso, D.; Kurnianto, S.; Stidham, M.; Kanninen, M. Mangroves among the most carbon-rich forests in the tropics. Nat. Geosci. 2011, 4, 293. [CrossRef]

6. Duarte, C.M.; Middelburg, J.J.; Caraco, N. Major role of marine vegetation on the oceanic carbon cycle. Biogeosci. Discuss. 2005, 1, 659-679. [CrossRef]

7. Alongi, D.M. Present state and future of the world's mangrove forests. Environ. Conserv. 2002, 29, 331-349. [CrossRef]

8. Alongi, D.M. Carbon Cycling and Storage in Mangrove Forests. Annu. Rev. Mar. Sci. 2014, 6, $195-219$. [CrossRef]

9. Thomas, N.; Lucas, R.; Bunting, P.; Hardy, A.; Rosenqvist, A.; Simard, M. Distribution and drivers of global mangrove forest change, 1996-2010. PLoS ONE 2017, 12, e0179302. [CrossRef]

10. Atwood, T.; Connolly, R.; Almahasheer, H.; Carnell, P.; Duarte, C.; Ewers Lewis, C.; Irigoien, X.; Kelleway, J.; Lavery, P.; Macreadie, P.; et al. Global patterns in mangrove soil carbon stocks and losses. Nat. Clim. Chang. 2017, 7, 523. [CrossRef]

11. Kauffman, J.B.; Donato, D.C. Protocols for the Measurement, Monitoring and Reporting of Structure, Biomass, and Carbon Stocks in Mangrove Forests; Center for International Forestry Research (CIFOR): Bogor, Indonesia, 2012.

12. Howard, J.; Hoyt, S.; Isensee, K.; Telszewski, M.; Pidgeon, E. (Eds.) Coastal Blue Carbon: Methods for Assessing Carbon Stocks and Emissions Factors in Mangroves, Tidal Salt Marshes, and Seagrasses; Conservation International, Intergovernmental Oceanographic Commission of UNESCO, International Union for Conservation of Nature: Arlington, VA, USA, 2014; p. 180.

13. Mcleod, E.; Chmura, G.L.; Bouillon, S.; Salm, R.; Björk, M.; Duarte, C.M.; Lovelock, C.E.; Schlesinger, W.H.; Silliman, B.R. A blueprint for blue carbon: Toward an improved understanding of the role of vegetated coastal habitats in sequestering $\mathrm{CO}_{2}$. Front. Ecol. Environ. 2011, 9, 552-560. [CrossRef] 
14. Feliciano, E.A.; Wdowinski, S.; Potts, M.D. Assessing Mangrove Above-Ground Biomass and Structure using Terrestrial Laser Scanning: A Case Study in the Everglades National Park. Wetlands 2014, 34, 955-968. [CrossRef]

15. Kauffman, J.B.; Heider, C.; Cole, T.G.; Dwire, K.A.; Donato, D.C. Ecosystem Carbon Stocks of Micronesian Mangrove Forests. Wetlands 2011, 31, 343-352. [CrossRef]

16. Watt, P.J.; Donoghue, D.N.M. Measuring forest structure with terrestrial laser scanning. Int. J. Remote Sens. 2005, 26, 1437-1446. [CrossRef]

17. Mascaro, J.; Asner, G.; Davies, S.; Dehgan, A.; Saatchi, S. These are the days of lasers in the jungle. Carbon Balance Manag. 2014, 9, 1-3. [CrossRef]

18. Hopkinson, C.; Chasmer, L.; Colin, Y.-P.; Treitz, P. Assessing forest metrics with a ground-based scanning lidar. Can. J. For. Res. 2004, 34, 573-583. [CrossRef]

19. McElhinny, C.; Gibbons, P.; Brack, C.; Bauhus, J. Forest and woodland stand structural complexity: Its definition and measurement. For. Ecol. Manag. 2005, 218, 1-24. [CrossRef]

20. Chave, J.; Andalo, C.; Brown, S.; Cairns, M.A.; Chambers, J.Q.; Eamus, D.; Fölster, H.; Fromard, F.; Higuchi, N.; Kira, T.; et al. Tree allometry and improved estimation of carbon stocks and balance in tropical forests. Oecologia 2005, 145, 87-99. [CrossRef] [PubMed]

21. Van Breugel, M.; Ransijn, J.; Craven, D.; Bongers, F.; Hall, J.S. Estimating carbon stock in secondary forests: Decisions and uncertainties associated with allometric biomass models. For. Ecol. Manag. 2011, 262, 1648-1657. [CrossRef]

22. Liang, X.; Kankare, V.; Hyyppä, J.; Wang, Y.; Kukko, A.; Haggrén, H.; Yu, X.; Kaartinen, H.; Jaakkola, A.; Guan, F.; et al. Terrestrial laser scanning in forest inventories. ISPRS J. Photogramm. Remote Sens. 2016, 115, 63-77. [CrossRef]

23. White, J.C.; Coops, N.C.; Wulder, M.A.; Vastaranta, M.; Hilker, T.; Tompalski, P. Remote Sensing Technologies for Enhancing Forest Inventories: A Review. Can. J. Remote Sens. 2016, 42, 619-641. [CrossRef]

24. Masek, J.G.; Hayes, D.J.; Joseph Hughes, M.; Healey, S.P.; Turner, D.P. The role of remote sensing in process-scaling studies of managed forest ecosystems. For. Ecol. Manag. 2015, 355, 109-123. [CrossRef]

25. Yang, X.; Strahler, A.H.; Schaaf, C.B.; Jupp, D.L.; Yao, T.; Zhao, F.; Wang, Z.; Culvenor, D.S.; Newnham, G.J.; Lovell, J.L. Three-dimensional forest reconstruction and structural parameter retrievals using a terrestrial full-waveform lidar instrument (Echidna ${ }^{\circledR}$ ). Remote Sens. Environ. 2013, 135, 36-51. [CrossRef]

26. Olsoy, P.J.; Glenn, N.F.; Clark, P.E.; Derryberry, D.R. Aboveground total and green biomass of dryland shrub derived from terrestrial laser scanning. ISPRS J. Photogramm. Remote Sens. 2014, 88, 166-173. [CrossRef]

27. Calders, K.; Newnham, G.; Burt, A.; Murphy, S.; Raumonen, P.; Herold, M.; Culvenor, D.; Avitabile, V.; Disney, M.; Armston, J.; et al. Nondestructive estimates of above-ground biomass using terrestrial laser scanning. Methods Ecol. Evol. 2015, 6, 198-208. [CrossRef]

28. Wallace, L.; Hillman, S.; Reinke, K.; Hally, B. Non-destructive estimation of above-ground surface and near-surface biomass using 3D terrestrial remote sensing techniques. Methods Ecol. Evol. 2017, 8, 1607-1616. [CrossRef]

29. Wallace, L.; Lucieer, A.; Watson, C.; Turner, D. Development of a UAV-LiDAR System with Application to Forest Inventory. Remote Sens. 2012, 4, 1519-1543. [CrossRef]

30. Smith, M.W.; Carrivick, J.L.; Quincey, D.J. Structure from motion photogrammetry in physical geography. Prog. Phys. Geogr. Earth Environ. 2015, 40, 247-275. [CrossRef]

31. Messinger, M.; Asner, G.; Silman, M. Rapid Assessments of Amazon Forest Structure and Biomass Using Small Unmanned Aerial Systems. Remote Sens. 2016, 8, 615. [CrossRef]

32. Koci, J.; Jarihani, B.; Leon, J.X.; Sidle, R.; Wilkinson, S.; Bartley, R. Assessment of UAV and Ground-Based Structure from Motion with Multi-View Stereo Photogrammetry in a Gullied Savanna Catchment. ISPRS Int. J. Geo-Inf. 2017, 6, 328. [CrossRef]

33. Cooper, S.; Roy, D.; Schaaf, C.; Paynter, I. Examination of the Potential of Terrestrial Laser Scanning and Structure-from-Motion Photogrammetry for Rapid Nondestructive Field Measurement of Grass Biomass. Remote Sens. 2017, 9, 531. [CrossRef]

34. Alonzo, M.; Andersen, H.-E.; Morton, D.; Cook, B. Quantifying Boreal Forest Structure and Composition Using UAV Structure from Motion. Forests 2018, 9, 119. [CrossRef] 
35. Niederheiser, R.; Mokros, M.; Lange, J.; Petschko, H.; Prasicek, G.; Elberink, S.O. Deriving 3D point clouds from terrestrial photographs comparison of different sensors and software. In Proceedings of the XXIII ISPRS Congress, Prague, Czech Republic, 12-19 July 2016; pp. 685-692.

36. Miller, J.; Morgenroth, J.; Gomez, C. 3D modelling of individual trees using a handheld camera: Accuracy of height, diameter and volume estimates. Urban For. Urban Green. 2015, 14, 932-940. [CrossRef]

37. Mikita, T.; Janata, P.; Surový, P. Forest stand inventory based on combined aerial and terrestrial close-range photogrammetry. Forests 2016, 7, 165. [CrossRef]

38. Puliti, S.; Ørka, H.; Gobakken, T.; Næsset, E. Inventory of Small Forest Areas Using an Unmanned Aerial System. Remote Sens. 2015, 7, 9632-9654. [CrossRef]

39. Zahawi, R.A.; Dandois, J.P.; Holl, K.D.; Nadwodny, D.; Reid, J.L.; Ellis, E.C. Using lightweight unmanned aerial vehicles to monitor tropical forest recovery. Biol. Conserv. 2015, 186, 287-295. [CrossRef]

40. Thiel, C.; Schmullius, C. Comparison of UAV photograph-based and airborne lidar-based point clouds over forest from a forestry application perspective. Int. J. Remote Sens. 2017, 38, 2411-2426. [CrossRef]

41. Abdollahnejad, A.; Panagiotidis, D.; Surový, P. Estimation and Extrapolation of Tree Parameters Using Spectral Correlation between UAV and Pléiades Data. Forests 2018, 9, 85. [CrossRef]

42. Giannetti, F.; Chirici, G.; Gobakken, T.; Næsset, E.; Travaglini, D.; Puliti, S. A new approach with DTM-independent metrics for forest growing stock prediction using UAV photogrammetric data. Remote Sens. Environ. 2018, 213, 195-205. [CrossRef]

43. Otero, V.; Van De Kerchove, R.; Satyanarayana, B.; Martínez-Espinosa, C.; Fisol, M.A.B.; Ibrahim, M.R.B.; Sulong, I.; Mohd-Lokman, H.; Lucas, R.; Dahdouh-Guebas, F. Managing mangrove forests from the sky: Forest inventory using field data and Unmanned Aerial Vehicle (UAV) imagery in the Matang Mangrove Forest Reserve, peninsular Malaysia. For. Ecol. Manag. 2018, 411, 35-45. [CrossRef]

44. Torresan, C.; Berton, A.; Carotenuto, F.; Di Gennaro, S.F.; Gioli, B.; Matese, A.; Miglietta, F.; Vagnoli, C.; Zaldei, A.; Wallace, L. Forestry applications of UAVs in Europe: a review. Int. J. Remote Sens. 2017, 38, 2427-2447. [CrossRef]

45. Bryson, M.; Johnson-Roberson, M.; Murphy, R.J.; Bongiorno, D. Kite Aerial Photography for Low-Cost, Ultra-high Spatial Resolution Multi-Spectral Mapping of Intertidal Landscapes. PLoS ONE 2013, 8, e73550. [CrossRef]

46. Mancini, F.; Dubbini, M.; Gattelli, M.; Stecchi, F.; Fabbri, S.; Gabbianelli, G. Using Unmanned Aerial Vehicles (UAV) for High-Resolution Reconstruction of Topography: The Structure from Motion Approach on Coastal Environments. Remote Sens. 2013, 5, 6880-6898. [CrossRef]

47. Lucieer, A.; Turner, D.; King, D.H.; Robinson, S.A. Using an Unmanned Aerial Vehicle (UAV) to capture micro-topography of Antarctic moss beds. Int. J. Appl. Earth Obs. Geoinf. 2014, 27, 53-62. [CrossRef]

48. B.O.M. Summary Statistics-Sunshine Coast Airport. Available online: http://www.bom.gov.au/climate/ averages/tables/cw_040861.shtml (accessed on 19 April 2018).

49. Leiper, G.; Leiper, G. Mangroves to Mountains: A Field Guide to the Native Plants of South-East Queensland; Logan River Branch, Society for Growing Australian Plants (Qld Region): Fortitude Valley, Australia, 2008.

50. CHC. CHC X91+ Datasheet. Available online: http://www.chcnav.com/index.php/welcome/search?key= x91\%2B (accessed on 15 October 2018).

51. DJI. Phantom 4 Pro V2.0. Available online: https://store.dji.com/product/phantom-4-pro-v2?vid=43151 (accessed on 20 October 2018).

52. White, J.C.; Wulder, M.A.; Vastaranta, M.; Coops, N.C.; Pitt, D.; Woods, M. The utility of image-based point clouds for forest inventory: A comparison with airborne laser scanning. Forests 2013, 4, 518-536. [CrossRef]

53. Greaves, H.E.; Vierling, L.A.; Eitel, J.U.H.; Boelman, N.T.; Magney, T.S.; Prager, C.M.; Griffin, K.L. Estimating aboveground biomass and leaf area of low-stature Arctic shrubs with terrestrial LiDAR. Remote Sens. Environ. 2015, 164, 26-35. [CrossRef]

54. Owers, C.J.; Rogers, K.; Woodroffe, C.D. Terrestrial laser scanning to quantify above-ground biomass of structurally complex coastal wetland vegetation. Estuarine Coast. Shelf Sci. 2018, 204, 164-176. [CrossRef]

55. Dandois, J.; Olano, M.; Ellis, E. Optimal Altitude, Overlap, and Weather Conditions for Computer Vision UAV Estimates of Forest Structure. Remote Sens. 2015, 7, 13895-13920. [CrossRef]

56. Newnham, G.; Armston, J.; Muir, J.; Goodwin, N.; Tindall, D.; Culvenor, D.; Püschel, P.; Nyström, M.; Johansen, K. Evaluation of Terrestrial Laser Scanners for Measuring Vegetation Structure; CSIRO: Perth, Australia, 2012. 
57. Pirotti, F.; Guarnieri, A.; Vettore, A. Ground filtering and vegetation mapping using multi-return terrestrial laser scanning. ISPRS J. Photogramm. Remote Sens. 2013, 76, 56-63. [CrossRef]

58. Liang, X.; Hyyppä, J.; Kaartinen, H.; Lehtomäki, M.; Pyörälä, J.; Pfeifer, N.; Holopainen, M.; Brolly, G.; Francesco, P.; Hackenberg, J.; et al. International benchmarking of terrestrial laser scanning approaches for forest inventories. ISPRS J. Photogramm. Remote Sens. 2018, 144, 137-179. [CrossRef]

59. Dandois, J.P.; Ellis, E.C. Remote Sensing of Vegetation Structure Using Computer Vision. Remote Sens. 2010, 2, 1157-1176. [CrossRef]

60. Wallace, L.; Lucieer, A.; Malenovský, Z.; Turner, D.; Vopěnka, P. Assessment of Forest Structure Using Two UAV Techniques: A Comparison of Airborne Laser Scanning and Structure from Motion (SfM) Point Clouds. Forests 2016, 7, 62. [CrossRef]

61. Roşca, S.; Suomalainen, J.; Bartholomeus, H.; Herold, M. Comparing terrestrial laser scanning and unmanned aerial vehicle structure from motion to assess top of canopy structure in tropical forests. Interface Focus 2018, 8. [CrossRef] [PubMed]

62. Lisein, J.; Pierrot-Deseilligny, M.; Bonnet, S.; Lejeune, P. A Photogrammetric Workflow for the Creation of a Forest Canopy Height Model from Small Unmanned Aerial System Imagery. Forests 2013, 4, 922-944. [CrossRef]

63. Yu, X.; Liang, X.; Hyyppä, J.; Kankare, V.; Vastaranta, M.; Holopainen, M. Stem biomass estimation based on stem reconstruction from terrestrial laser scanning point clouds. Remote Sens. Lett. 2013, 4, 344-353. [CrossRef]

64. Cole, T.G.; Ewel, K.C.; Devoe, N.N. Structure of mangrove trees and forests in Micronesia. For. Ecol. Manag. 1999, 117, 95-109. [CrossRef]

65. Cook, K.L. An evaluation of the effectiveness of low-cost UAVs and structure from motion for geomorphic change detection. Geomorphology 2017, 278, 195-208. [CrossRef]

66. Cunliffe, A.M.; Brazier, R.E.; Anderson, K. Ultra-fine grain landscape-scale quantification of dryland vegetation structure with drone-acquired structure-from-motion photogrammetry. Remote Sens. Environ. 2016, 183, 129-143. [CrossRef]

67. Javernick, L.; Brasington, J.; Caruso, B. Modeling the topography of shallow braided rivers using Structure-from-Motion photogrammetry. Geomorphology 2014, 213, 166-182. [CrossRef]

68. Frazer, G.; Magnussen, S.; Wulder, M.; Niemann, K. Simulated impact of sample plot size and co-registration error on the accuracy and uncertainty of LiDAR-derived estimates of forest stand biomass. Remote Sens. Environ. 2011, 115, 636-649. [CrossRef]

69. Muir, J.; Goodwin, N.; Armston, J.; Phinn, S.; Scarth, P. An Accuracy Assessment of Derived Digital Elevation Models from Terrestrial Laser Scanning in a Sub-Tropical Forested Environment. Remote Sens. 2017, 9, 843. [CrossRef]

(C) 2019 by the authors. Licensee MDPI, Basel, Switzerland. This article is an open access article distributed under the terms and conditions of the Creative Commons Attribution (CC BY) license (http://creativecommons.org/licenses/by/4.0/). 